\title{
Changes in metabolic and immunological variables of wild and pond-reared southern white shrimp Litopenaeus schmitti adult males during continuous reproductive activity
}

\author{
Lourdes Pérez-Jar ${ }^{\mathrm{a}, \mathrm{d}}$, Tania Rodríguez-Ramos ${ }^{\mathrm{b}}$, Laida Ramos ${ }^{\mathrm{b}}$, \\ Yasel Guerra-Borrego ${ }^{\mathrm{c}}$, Ilie S. Racotta ${ }^{\mathrm{d}, *}$ \\ ${ }^{a}$ Centro de Investigaciones Pesqueras, Ministerio de la Industria Pesquera, 5ta Ave. y 246, Barlovento, Santa Fe, Playa, \\ Ciudad de La Habana 19100, Cuba \\ ${ }^{\mathrm{b}}$ Centro de Investigaciones Marinas, Universidad de La Habana, Calle $16 N^{\circ} 114$, Playa, Ciudad de La Habana 11300, Cuba

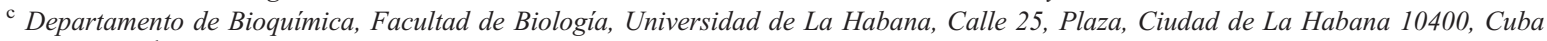 \\ d Programa de Acuicultura, Centro de Investigaciones Biológicas del Noroeste, (CIBNOR), Mar Bermejo 195, \\ Col. Playa Palo de Santa Rita, La Paz, B.C.S. 23090, México
}

Received 24 February 2005; received in revised form 13 July 2005; accepted 24 July 2005

\begin{abstract}
Reproductive performance of male southern white shrimp Litopenaeus schmitti decreased over time possibly attaining a reproductive exhaustion that results in a lower physiological condition that includes a decreased immune response capacity. Several indicators of immune and metabolic status such as phenoloxidase activity (PO), total hemocytes count (THC), hemoagglutinating activity (HA), total proteins, and glucose concentration in the hemolymph were analyzed in wild and pond-reared adult males at 3,30, and 60 days after introduction to a production cycle in a commercial hatchery. High PO activity, high levels of glucose, and low levels of protein in the hemolymph suggest a general stress condition at the beginning of the production cycle because of the manipulation involved when animals were transferred to the hatchery. As indicated by initial levels of glucose, wild shrimp are more susceptible to such stress. After one month, all indicators suggest optimal conditions for shrimp, which, however, deteriorated in the second month when higher PO activity and lower levels of THC, hemoagglutinating activity, glucose, and proteins were observed, compared to values at 30 days. These results indicate that after a certain period under laboratory conditions associated with high reproductive activity, males of L. schmitti have a depressed overall physiological status and should be replaced.
\end{abstract}

(C) 2005 Elsevier B.V. All rights reserved.

Keywords: Broodstock; Crustacean; Defence system; Glucose; Phenoloxydase; Stress

\footnotetext{
* Corresponding author.

E-mail address: iracotta@cibnor.mx (I.S. Racotta).
} 


\section{Introduction}

World production of marine shrimp increased during the last 20 years, mainly as a result of an increase in the area of pond cultivation and higher stocking densities. However, unfavourable environmental conditions and high densities induce stress that, in turn, diminish the immune system response of the animals and increase their susceptibility to illness. Evaluation of metabolic variables of the hemolymph and the response of the immune system is useful to measure stress caused by conditions in captivity conditions (Sánchez et al., 2001; Perazzolo et al., 2002; Pascual et al., 2003). Additionally, shrimp domesticated over several generations have alterations in carbohydrate and protein metabolism that could compromise the immune system (Pascual et al., 2004).

For the specific case of Litopenaeus schmitti broodstock, negative influence of high temperatures was observed for some biological markers of the immune response such as the hemoagglutinating activity and its relationship with the sperm quality of males (Rodríguez-Ramos et al., 2001; Marrero et al., 2002). Pérez (1996) observed that reproductive performance of $L$. schmitti broodstock decreased over time in terms of female chasing by males and fertilization rate, traits that are mainly attributed to the condition of males. This decline can be observed in several penaeid species and it has been proposed that this is a result of a lower general physiological condition, known as reproductive exhaustion (for review see Racotta et al. (2003)). This state could include depressed immunological response capacities.

In this study, we evaluated indicators of immunological and metabolic status of wild and pond-reared male L. schmitti broodstock during a 60-day reproduction cycle to determine differences between wild and pond-reared shrimp and assess if deterioration of immune system capacities occurs.

\section{Materials and methods}

\subsection{Origin of broodstock and general management}

Seven-month-old pond-reared mature males were collected in ponds of the laboratory YAGUACAM, (Cienfuegos Province, Cuba), whereas wild mature males were captured in the Gulf of Guacanayabo, Granma Province, Cuba by trawling. In both cases, animals were transferred to the maturation rooms at the laboratory of commercial production at YAGUACAM.

Males were maintained separately from females (Browdy et al., 1996) in five different tanks (surface area $16 \mathrm{~m}^{2}$ ) for each origin and stocked at a density of 7 males $/ \mathrm{m}^{2}$, with a daily water exchange of $200 \%$, continuous aeration and artificial photoperiod of 14:10 h (light-darkness). Frozen squid (Loligo sp.) was provided in three rations at $20 \%$ of the total shrimp fresh weight, along with an artificial diet (Zeigler Brothers, Inc.) of two rations at $2 \%$ of the total shrimp fresh weight. Shrimp were maintained in captivity during a reproduction cycle of 60 days. Specimens were sampled at 3, 30, and 60 days after introduction to the maturation room. Each sampling consisted of 15 wild and 15 pond-reared shrimp in intermolt stage $6 \mathrm{~h}$ before feeding.

\subsection{Preparation of the hemolymph samples}

The hemolymph $(200 \mu \mathrm{L})$ was obtained with a 1$\mathrm{mL}$ syringe and a $20-\mathrm{G}$ needle, from the ventral sinus using EDTA in isotonic solution as an anticoagulant (Vargas-Albores et al., 1993a) but with equal proportions of anticoagulant and hemolymph. Total hemolymph was used for total hemocyte count whereas for the other determinations hemolymph was centrifuged for $10 \mathrm{~min}$ at $800 \times g$ at $4{ }^{\circ} \mathrm{C}$ to obtain plasma.

\subsection{Determination of the effectors of the immune response}

To determine phenoloxidase activity (PO), $10 \mu \mathrm{L}$ plasma were placed on a microplate and $250 \mu \mathrm{L} \mathrm{L}$ DOPA were added; the mixture was incubated for 20 min and read at $492 \mathrm{~nm}$. The specific phenoloxidase activity was calculated according to HernándezLópez et al. (1996). For the total hemocyte count (THC), $25 \mu \mathrm{L}$ hemoplymph were mixed with $75 \mu \mathrm{L}$ cold Alsever solution (glucose $113 \mathrm{mM}$, sodium citrate $27.2 \mathrm{mM}$, citric acid $2.8 \mathrm{mM}$, and sodium chloride $71.9 \mathrm{mM}$, with a final formaldehyde concentration of $4 \%$ ). The count was carried out using a Neubauer chamber under a microscope. The determination of hemoagglutinating activity (HA) was done 
according to Vargas-Albores et al. (1993b), modified by Rodríguez-Ramos et al. (2001). Briefly, erythrocyte type $0+$ of human blood were obtained from Provincial Blood Bank of Havana, subjected to a formaldehyde process to guarantee their preservation (less than four months), and diluted to obtain a 5\% suspension in PBS (phosphate-buffered saline: $\mathrm{NaCl}$ $0.01 \mathrm{M}, \mathrm{KH}_{2} \mathrm{PO}_{4} 0.15 \mathrm{M}$, and $\mathrm{Na}_{2} \mathrm{HPO}_{4} 0.15 \mathrm{M}$, pH 7.4). Serial dilutions of plasma samples with $\mathrm{PBS}$ were done in multi-excavated U-plates, $20 \mu \mathrm{L}$ of human erythrocytes suspension were added and the plates were incubated at ambient temperature for $2 \mathrm{~h}$. HA was recorded as the reciprocal of the last dilution in which a positive reaction (agglutination) was observed in relation to controls, where the shrimp plasma was substituted by PBS.

\subsection{Biochemical variables}

The concentration of proteins was determined by means of the commercial kit Biuret (Merck), after diluting the hemolymph sample to measure between 1 and $10 \mathrm{mg} / \mathrm{mL}$ protein. The concentration of glucose was determined using a commercial kit (GOD-PAP, Randox).

\subsection{Statistical analyses}

STATISTICA (version 7.0) software (StatSoft, Inc. 2001, Tulsa, OK, USA) was used for statistical analyses. Two-way ANOVA, followed by Tukey's posthoc mean comparison test was used to assess for significant differences between animal origins (wild or pond-reared) and sampling periods (3, 30, and 60 days) for the different measured variables. For the total number of hemocytes and hemoagglutinating activity, data were transformed to logarithm base 10 to fit a normal distribution. Data are reported as the mean \pm standard error. The level of significance was preset at $P<0.05$ for all analyses.

\section{Results}

\subsection{Immunological indicators}

Three days after their placement in the maturation room, pond-reared and wild shrimp had similar values of PO activity in plasma. This activity significantly decreased after a month in the production cycle in both groups and after two months it increased significantly, especially in wild shrimp (Fig. 1A). Values of THC did not differ between groups three days after placement of the specimens to the maturation room. After one month, no significant differences were observed between the two groups or with the first sampling. After two months, THC significantly decreased compared to the first and second samplings, independent of the origin of the shrimp (Fig. 1B). HA showed similar results to those observed for THC: a significant decrease was observed after two months, independent of the origin of the shrimp (Fig. 1C).

\subsection{Biochemical variables}

The concentration of total proteins in the hemolymph increased significantly in both groups after one month. Concentration of protein decreased again by the second month in both groups, although significant differences with the previous sampling of 30 days were observed only for wild shrimp (Fig. 2A). Initial concentrations of glucose were significantly higher in wild than in pond-reared shrimp. In both groups, glucose decreased over time, attaining very low levels $(<10 \mathrm{mg} / \mathrm{dL})$ after 60 days (Fig. 2B).

\section{Discussion}

\subsection{Initial values and stress}

Although not measured in animals before their transfer to the laboratory, several indicators, such as high PO activity, high levels of glucose, and low levels of protein in the hemolymph, suggest that, at the beginning of the productive cycle, a general stress condition was present from the transfer of animals to the hatchery. Glucose is one of the better recognized variables associated with stress in penaeid shrimp (Racotta and Palacios, 1998; Hall and Van Ham, 1998). The initial values obtained in this study (near or above $40 \mathrm{mg} / \mathrm{dL}$ ) fall in the range of values commonly reported for stressed shrimp (for review see Pascual et al. (2003)) and thus could be explained as a stress response to the transfer to maturation tanks. Higher levels of glucose in wild shrimp indicate that 


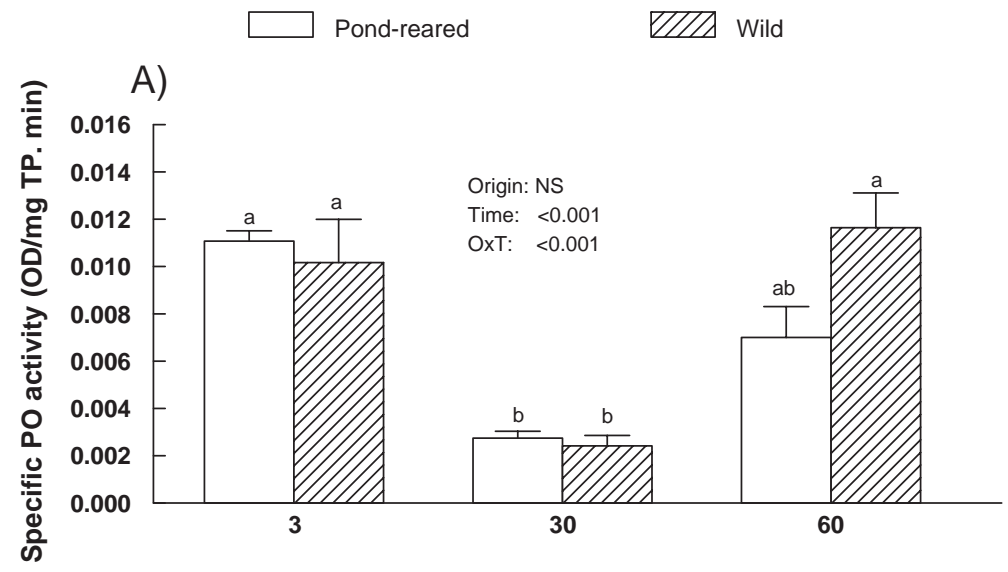

B)

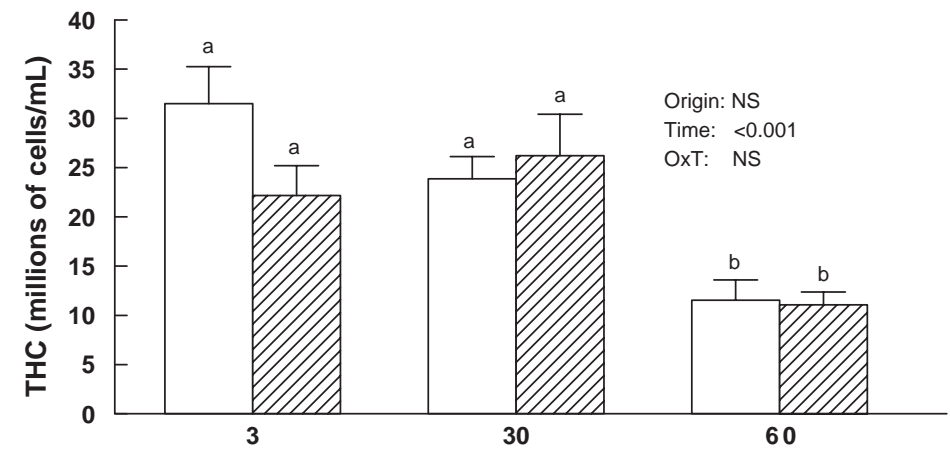

C)

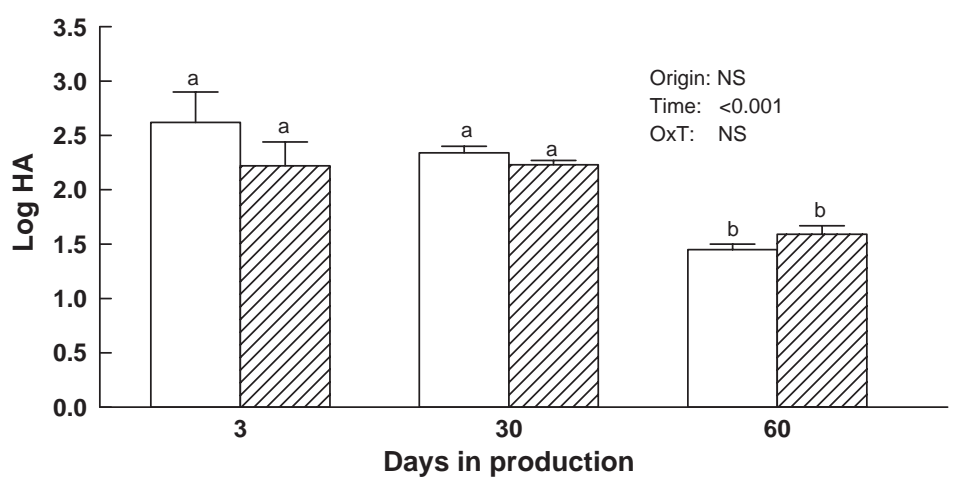

Fig. 1. A) Specific phenoloxidase (PO) activity, B) total hemocyte count (THC) and C) hemoagglutinating activity (HA) in hemolymph of pondreared and wild shrimp sampled after stocking in maturation tanks during their reproduction cycle. OD: Optical density and TP: total proteins. $n=15$ for each sampling. Data are expressed as mean \pm standard error; two-way ANOVA results are indicated. Different letters indicate significant differences $(P<0.05)$.

they are more susceptible to stress from transfer and stocking under intensive conditions because wild shrimp are normally not subjected to human manipulation and transfer stress and transport was longer than for pond-reared shrimp. The concentration of proteins is not as closely associated with stress, although some studies reported a decrease in protein levels during acute stress (Racotta and Palacios, 

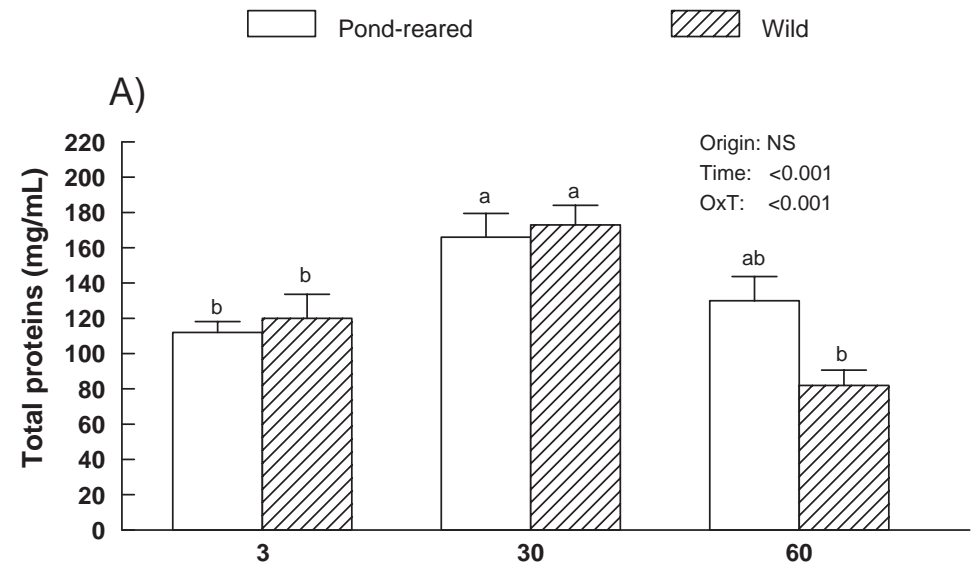

B)

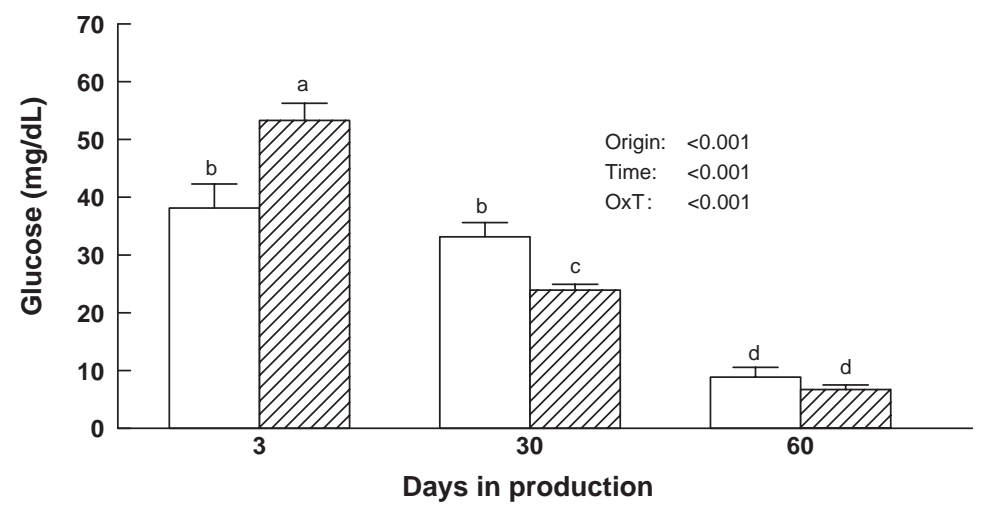

Fig. 2. Concentration of A) total proteins and B) glucose in pond-reared and wild shrimp sampled after stocking in maturation tanks during the reproduction cycle. $n=15$ for each sampling and two-way ANOVA results are indicated in the table. See Fig. 1 for statistics.

1998), 7 days after eyestalk ablation or spermatophore extirpation (Perazzolo et al., 2002). Protein levels in the initial sampling can be considered as relatively low, compared to the levels obtained from the second sampling and to the levels reported for other penaeid spawners (Palacios et al., 2000; Rosas et al., 2004). An increase in PO as a stress response is supported by higher PO activity in shrimp several days after transfer to laboratory conditions, compared to those sampled directly from ponds (Sánchez et al., 2001; RodríguezRamos, 2003). In other stressful situations, such as eyestalk ablation in females or male spermatophore extirpation (Perazzolo et al., 2002) and exposure to acute hypoxia (Le Moullac et al., 1998), an increase in PO activity was also reported. In this study, phenoloxidase (PO) values in plasma (0.01-0.011 absorbance units) at initial sampling (3 days) were higher than those obtained by Rodríguez-Ramos (2003), who obtained hemolymph from adults immediately after being captured from growing ponds $(0.003 \pm 0.0003$ absorbance units).

\subsection{Changes over time}

One month after the beginning of the reproductive cycle (second sampling), shrimp in both groups apparently showed healthy or normal metabolic and immunological condition. Lowest PO activity after 30 days, compared to the initial sampling, suggest an adaptation to maturation conditions because the levels are similar to those of shrimp in ponds (RodríguezRamos, 2003). An optimal physiological condition of shrimp one month after their stocking in maturation conditions is also suggested by the levels of glucose 
and proteins, as well as by the optimal sperm quality at this sampling (Pérez-Jar, unpublished results). Glucose levels between 20 and $30 \mathrm{mg} / \mathrm{dL}$ lie more closely within the normal range for penaeids (Racotta and Palacios, 1998; Pascual et al., 2003) than the initial values and, thus, could reflect a situation free of manipulation and nutritional stress. The increase in protein levels from low initial values could indicate an adaptation of animals to maturation conditions, as concluded from PO and glucose levels. Accordingly, the protein level in hemolymph is a good indicator of the quality of the diet (Cedeño et al., 2000; Pascual et al., 2003) and general health status (Rodríguez et al., 2000).

At the end of the reproduction cycle (60 days in the maturation tank), practically all indicators suggest poor physiological and health condition. High PO values were obtained again and also a significant decrease in THC and HA occurred. During microbial infections, there is activation of the PO system, involving the liberation of the content of semi-granular and granular hemocytes (Soderhall et al., 1994; VargasAlbores and Yepiz-Plascencia, 2000). Additionally, there is an aggregation of hemocytes in organs subjected to microbial infection, which reduces the number of circulating hemocytes (Paterson et al., 1976; Smith and Soderhall, 1983). Although we did not analyze the presence of pathogens in the hemolymph, large quantities of bacteria were observed in the spermatic mass of males after 60 days, indicating that shrimp were facing a general bacterial infection that could result in high PO activity and low THC. A decline in hemoagglutinating activity was also observed in the last sampling and could be indicative of microbial infection. Levels of total protein and glucose also declined in the last sampling along with declines in reproductive performance indicators, total sperm count, and percentage of normal sperm (Pérez-Jar, unpublished results). These variables are more indicative of poor physiological status resulting from reproductive exhaustion (Racotta et al., 2003). Taken together, these results indicate that, after a certain period under laboratory conditions associated with high reproductive activity, L. schmitti males seem to reach a depressed overall physiological status and should be replaced after two months. It remains to be determined if microbial infection, together with reproductive exhaustion, acts synergistically to cause this status or if the depressed status results in a lower immune response capacity that allowed microbial infection. In this context, continuous and forced reproduction represents a chronic stress situation, which may reduce their resistance to bacteria inhabiting the marine environment, as shown in other studies assessing stressful situations (Le Moullac et al., 1998; Sánchez et al., 2001; Perazzolo et al., 2002).

\subsection{Broodstock origin}

In addition to differences for initial glucose levels previously discussed, there is a more pronounced decline in protein levels and increase in PO activity in wild than in pond-reared shrimp at the end of the reproduction cycle. These results, together with a more pronounced decline in reproductive performance and sperm quality of wild males (Pérez-Jar, unpublished results), suggest that wild shrimp are more susceptible to reproductive exhaustion and chronic stress than pond-reared shrimp.

\section{Acknowledgments}

The authors are grateful to the shrimp hatchery YAGUACAM for donation of specimens. We thank J. Hernández and G. Espinosa for their suggestions on determination of immunological variables and $\mathrm{E}$. Palacios for her critical review of the manuscript. The editor at CIBNOR modified the English text. This research was partially supported by a grant to I.S. Racotta from CONACYT (grant 43249). L. PérezJar is a doctoral student fellow of CONACYT at CIBNOR.

\section{References}

Browdy, C.L., McGovern-Hopkins, K., Stokes, A.D., Hopkins, J.S., Sandifer, P.A., 1996. Factors affecting the reproductive performance of the Atlantic white shrimp, Penaeus setiferus, in conventional and unisex tank systems. J. Appl. Aquac. 6, $11-25$.

Cedeño, R., Valenzuela, E., Rodríguez, J., 2000. Efectores inmunitarios como marcadores de deficiencias nutricionales en dietas para Litopenaeus vannamei. Panor. Acuícola 5, 42-44.

Hall, M.R., Van Ham, E.H., 1998. The effects of different types of stress on blood glucose in the giant tiger prawn Penaeus monodon. J. World Aquac. Soc. 29, 290-299. 
Hernández-López, J., Gollas-Galván, T., Vargas-Albores, F., 1996. Activation of the prophenoloxidase system of the brown shrimp (Penaeus californiensis Holmes). Comp. Biochem. Physiol. 113C, 61-66.

Le Moullac, G., Soyez, C., Saulnier, D., Ansquer, D., Avarre, J.C., Levy, P., 1998. Effect of hypoxic stress on the immune response and resistance to vibriosis of the shrimp Penaeus stylirostris. Fish Shellfish Immunol. 8, 621-629.

Marrero, J., Espinosa, G., Alonso, M.E., Bécquer, U., Borrell, Y., Rodríguez-Ramos, T., Herrera, M.B., 2002. Efecto del LPS de E. coli en el número de hemocitos y la producción de óxido nítrico en el camarón blanco (Litopenaeus schmitti). Rev. Investig. Mar. 23, 56-63.

Palacios, E., Ibarra, A.M., Racotta, I.S., 2000. Tissue biochemical composition in relation to multiple spawning in wild and pond-reared Penaeus vannamei broodstock. Aquaculture 185, $353-371$.

Pascual, C., Gaxiola, G., Rosas, C., 2003. Blood metabolites and hemocyanin of the white shrimp, Litopenaeus vannamei: the effect of culture conditions and a comparison with other crustacean species. Mar. Biol. 142, 735-745.

Pascual, C., Arena, L., Cuzón, G., Gaxiola, G., Taboada, G., Valenzuela, M., Rosas, C., 2004. Effect of size-based selection program on blood metabolites and immune response of Litopenaeus vannamei juveniles fed different dietary carbohydrate levels. Aquaculture 230, 405-416.

Paterson, W.D., Stewart, J.E., Zwicker, B.M., 1976. Phagocytosis as cellular immune response mechanisms in the American lobster, Homarus americanus. J. Invertebr. Pathol. 27, 95-104.

Perazzolo, L.M., Gargioni, R., Ogliari, P., Barracco, M.A.A., 2002. Evaluation of some hemato-immunological parameters in the shrimp Farfantepenaeus paulensis submitted to environmental and physiological stress. Aquaculture 214, 19-33.

Pérez, L., 1996. Obtención de progenitores de cultivo del camarón blanco Penaeus schmitti a escala comercial. Masters Thesis. Centro de Investigaciones Marinas, Universidad de La Habana, $44 \mathrm{pp}$.

Racotta, I.S., Palacios, E., 1998. Hemolymph metabolic variables in response to experimental manipulation stress and serotonin injection in Penaeus vannamei. J. World Aquac. Soc. 29, $351-356$.

Racotta, I.S., Palacios, E., Ibarra, A.M., 2003. Shrimp larval quality in relation to broodstock condition. Aquaculture 227, 107-130.
Rodríguez, J., Cedeño, R., Molina, C., Otero, V., Valenzuela, E., Sotomayor, M.A., 2000. Efecto de la calidad de la dieta sobre la respuesta inmune del camarón Penaeus vannamei. In: CruzSuárez, L.E., Ricque-Marie, D., Tapia-Salazar, M., OlveraNovoa, M.A., y Civera-Cerecedo, R. (Eds.), Avances en Nutrición Acuícola V. Memorias del V Simposium Internacional de Nutrición Acuícola 19-22 Noviembre, 2000. Mérida, México.

Rodríguez-Ramos, T., 2003. Evaluación de cuatro efectores de la respuesta inmune innata en condiciones de estrés, en el camarón blanco Litopenaeus schmitti. Master Thesis. Centro de Investigaciones Marinas, Universidad de La Habana, Julio 2003, 72 pp.

Rodríguez-Ramos, T., Borrell, Y., Ramos, L., Bécquer, U., Espinosa, G., 2001. Aplicación de la actividad hemoaglutinante de la hemolinfa de Litopenaeus schmitti. Rev. Investig. Mar. 22, $235-240$

Rosas, C., Cooper, E.L., Pascual, C., Brito, R., Gelabert, R., Moreno, T., Miranda, G., Sánchez, A., 2004. Indicators of physiological and immunological status of Litopenaeus setiferus wild populations (Crustacea Penaeidae). Mar. Biol. 145, 401-413.

Sánchez, A., Pascual, C., Sánchez, A., Vargas-Albores, F., LeMoullac, G., Rosas, C., 2001. Hemolymph metabolic variables and immune response in Litopenaeus setiferus adult males: the effect of acclimation. Aquaculture 198, 13-28.

Smith, V.J., Soderhall, K., 1983. Induction of desgranulation and lysis of haemocytes in the freshwater crayfish Astacus astacus, by components of the prophenoloxidase activating system in vitro. Cell Tissue Res. 133, 295-303.

Soderhall, K., Cerenius, L., Johansson, M.W., 1994. The proPO system and its role in invertebrate defense. Ann. N. Y. Acad. Sci. 712, 155-161.

Vargas-Albores, F., Yepiz-Plascencia, G., 2000. B-glucan binding protein and its role in shrimp immune response. Aquaculture 191, 13-21.

Vargas-Albores, F., Guzmán, M.A., Ochoa, J.L., 1993a. An anticoagulant solution for haemolymph collection and prophenoloxidase studies of penaeid shrimp Penaeus californiensis. Comp. Biochem. Physiol. 106A, 299-303.

Vargas-Albores, F., Guzman, M.A., Ochoa, J.L., 1993b. A lipopolysaccharide/binding aglutinin isolated from brown shrimp (Penaeus californiensis Holmes) haemolymph. Comp. Biochem. Physiol. 104B, 407-413. 